\title{
Delivery of Ecosystem Services by Community Woodland Groups and Their Networks
}

\author{
Mike Dunn ${ }^{1, * \mathbb{C}}$, Bianca Ambrose-Oji ${ }^{2}$ and Liz $\mathrm{O}^{\prime}$ Brien $^{3}{ }^{2}$ \\ 1 Forest Research, Northern Research Station, Roslin EH25 9SY, UK \\ 2 Forest Research, 620 Bristol Business Park, Bristol BS16 1EJ, UK; bianca.ambrose-oji@forestresearch.gov.uk \\ 3 Forest Research, Alice Holt Lodge, Farnham GU10 4LH, UK; liz.obrien@forestresearch.gov.uk \\ * Correspondence: michael.dunn@forestresearch.gov.uk
}

Citation: Dunn, M.; Ambrose-Oji, B.; O'Brien, L. Delivery of Ecosystem Services by Community Woodland Groups and Their Networks. Forests 2021, 12, 1640. https://doi.org/ $10.3390 /$ f12121640

Academic Editor: Isabella De Meo

Received: 29 September 2021

Accepted: 23 November 2021

Published: 26 November 2021

Publisher's Note: MDPI stays neutral with regard to jurisdictional claims in published maps and institutional affiliations.

Copyright: (c) 2021 by the authors. Licensee MDPI, Basel, Switzerland. This article is an open access article distributed under the terms and conditions of the Creative Commons Attribution (CC BY) license (https:/ / creativecommons.org/licenses/by/ $4.0 /)$.

\begin{abstract}
The Millennium Ecosystem Assessment stresses that it is possible to manage ecosystems so as to strengthen their capacity to provide a range of goods and services. In reality, the delivery of ecosystem services reflects policy and delivery mechanisms, the environment, and the objectives of landowners and managers. Amid gradual changes to forest policy and more recent periods of austerity, the management of treescapes by locally led groups, such as Community Woodland Groups (CWGs), has become increasingly common. Through document analysis and interviews we explore the objectives and activities of British-based CWGs, and the implications these have for the delivery of ecosystem services. Additionally, we explore CWGs involvement with three types of networks and the ways in which each facilitate CWGs' establishment, operations and ecosystem service provision. We conclude that, while CWGs are capable of delivering a range of ecosystem services, their focus is typically on: (i) cultural services for the benefit of the local community, and (ii) biodiversity. Since these foci parallel the goods and services emphasised in contemporary forest policy agendas, it is apparent that CWGs represent a promising model for woodland management. However, to realise their potential and confront management challenges, CWGs often rely on access to advice, labour, equipment and funding from across multiple networks.
\end{abstract}

Keywords: community Woodland group; ecosystem services; cultural; networks

\section{Introduction}

The Millennium Ecosystem Assessment was designed to highlight the relationship between ecosystems and human wellbeing at several spatial scales, from the global to the local. It aimed to raise policy makers' and managers' awareness of the importance of ecosystems in defining human well-being around the globe, and strived to build the capacity of all role players to conduct integrated ecosystem assessments and to manage ecosystems to strengthen their capacity to provide goods and services [1]. From a forestry perspective, this call represented a natural next step in the evolution of understandings and management of forest resources, away from what was retrospectively termed 'a storehouse of timber' [2]. Indeed, German-led productivist and industrial notions of forestry-typified by sharp, linear boundaries, even-aged monocultural forests and sustained yield-had, in many parts, already given way to new notions acknowledging a larger and more diverse range of potential benefits. Terms, such as post-industrial forestry, new forestry, holistic forestry, kinder and gentler forestry, sustainable forestry, multi-value forest management, multi-resource forest management, and forest ecosystem management [3-5] have all been used to reflect a growing emphasis on the provision of 'an optimum mix of human-valued products and services' [6].

In parallel to changes in understandings about what a forest resource can or should provide, there have also been challenges to the traditional sovereignty of the forestry administration and its 'scientific' foresters [5]. Although central governments own, by far, the greatest proportion of the world's 5.4 billion hectares of forests and wooded areas, recent 
decades have seen a move away from the centrally administered, top-down regulatory policies that characterised much of the 19th and 20th centuries [7]. This decentralisation has, in part, been driven by demands for a greater recognition of local communities' needs for forest products and their role in managing local forests for multiple purposes [8]. The opportunity to transfer management responsibilities has also allowed many governments to reduce the financial burden of forest governance amidst substantial fiscal and budgetary pressures, and to diminish their accountability for challenges, such as biological conservation and the prevention of deforestation [8,9]. As a result of such demand and opportunity, many government-owned forests have come to be managed as common property for multiple uses by local communities and community-based organisations [7]. In fact, local communities now manage approximately $13 \%$ of forests globally [9].

Some argue that community management of resources may be preferable to that offered by the state, since community organisations foster locally-led decision making, monitoring and rule of enforcement [10,11]. Similarly, community perspectives may be deemed essential, given that communities are often neglected yet are integral parts of local level ecosystem management [12]. Their roles, including knowledge, experience, institutions, and organisational capabilities, should arguably be acknowledged and embedded in any governance system that aims at strengthening the capacity to manage ecosystems sustainably for human wellbeing [12], as the Millennium Ecosystem Assessment demands. However, the governance of resources by local communities is highly variable; while some have proved successful in terms of ecosystem service provision and forest protection, others fail to take action to prevent overuse and degradation [13]. The latter is often associated with finite resources, whereby one person's use reduces availability or access for others. As such, this threat is most acute in the context of small resource pools (e.g., small forests) with highly coveted resources (e.g., valuable timber) [13].

However, the growth and expansion of community forest management globally has been accompanied by a body of research that has sought to identify the conditions associated with positive forest and livelihood outcomes. A synthesis of this body of work distinguished exogenous factors (tenure security, government support, and effective and appropriate regulatory frameworks) from governance and institutional factors (local rulemaking autonomy, monitoring and sanctioning, local organisation, social capital, and leadership) [9]. While some of these factors may be beyond the control of community forest managers, a focus on other, more controllable factors may still allow for instrumental improvements in livelihoods and forest conditions. For example, an examination of ten case studies identified a 'Community of Practice'—defined as a high degree of networking among internal and external stakeholders based on common concerns, social learning and mutual respect-as the key driving force for success [14]. In the context of forest and woodland management networks, others have also drawn attention to the influence stakeholders can wield over the management of ecosystem services, particularly enablers and regulators with the capacity to set formal and informal rules and regulations which impinge on others behaviour and practices [15].

Arguably, a community's capacity to effectively carry out long-term management of ecosystem services is dependent on the establishment of a knowledge network [16]. These networks enable adaptive actors working at different levels to share information [17], increasing the knowledge base for management and creating new awareness about the processes underlying the functioning of social and ecological systems [16]. In addition to building knowledge, networks with other communities, organisations and agencies facilitate increased community resilience and sustainability [18] and enable communities to co-opt new techniques and technologies from outsiders or newcomers, particularly if the community has previously been isolated or otherwise disconnected [16].

Although networks can enable greater learning and co-operation [19] which may underpin ecosystem service delivery, accruing such benefits depends on awareness of the available information or support within the network, as well as perceptions of value, cost and accessibility [20]. Network structure and power relations are also hugely important, 
offering potential benefits, such as the approval of projects and funding [21]. Conversely, funding may prove inaccessible if the ambitions of applicants differ from that of those holding power [22]. Similarly, groups may be compelled to set aside their ambitions to pursue those outlined by funders, as was the case for participants of the Canadian Model Forest Program [23]. Diversity and engagement across networks is also important if new understandings and positive change are to result [24].

For much of its history, the people of Britain enjoyed common rights to the land. Even after the 11th century Norman conquest, royal hunting rights coincided with the rights of ordinary people to gather firewood, fruit and fungi, and to use land for grazing and pannage. However, these rights became increasing exclusive from the late 18th century, and until the 20th century forests remained largely in private ownership [25]. In the 1980s, the aforementioned shift towards multi-objective forestry, together with the government's privatisation policy, opened the door for local communities to purchase parts of the Forestry Commission's estate. This signalled the dawning of today's Community Woodland Groups (CWGs), defined as 'a community led group which takes an active role (either independently or under supervision) in the management of a woodland which it may own or lease or work in under the owner's permission' [26]. Britain's CWGs come in various guises, such as "Friends of ... ", "Conservation Group”, "Environment Group" and "Volunteer Group". Similarly, the range and extent of activities these groups are involved in varies from a couple of volunteers keeping a watchful eye on a small number of trees, to a more proactive group of volunteers managing local woodland for community benefit. The majority of groups have some formal constitution to enable them to handle funds or own land [25], yet many manage woodlands on land owned by others. Although CWGs are collectively diverse in their governance [27-29], they are united by the involvement of volunteers and an objective to protect and care for a piece of land within the community. Such groups have grown in number and responsibility as public bodies across Britain have transferred ownership and management of land judged to be burdensome or neglected [30]. In fact, there are now over 300 CWGs in England, 200 in Scotland and 150 in Wales [31].

Although some CWGs may have relatively modest ambitions, even the most determined to deliver particular ecosystem goods and services may be hindered by a lack of capacity and resources [32,33]. Previous studies have revealed a strong desire for locallevel networking amongst CWGs for the purpose of practical problem solving, shared learning and access to equipment and services [27,29,33], all of which may impact on a CWGs' ability to deliver ecosystem services. In spite of such desires, networking and sharing of support between CWGs has been found to be lacking [33]. In addition to other CWGs, actors, such as volunteer groups and scientists, may be valuable for expanding networks and knowledge sharing [14,34]. Woodland officers, employed by public bodies or charities, can also be particularly valuable contacts for CWGs owing to their technical expertise, management support and promotion of CWGs to others. However, it has been noted that, as non-traditional woodland managers, CWGs sometimes experience difficulty in accessing these individuals [33]. Conversely, CWGs may be part of long-established national volunteer networks and initiatives which offer only indirect benefits for ecosystem service delivery. For example, a majority of 22 English CWGs were found to be members of the British Trust for Conservation Volunteers (BTCV)—now The Conservation Volunteers (TCV)-purely to access volunteer insurance. Many of this cohort were also registered with the Woodland Trust Community Woodland Network but confessed to not being actively involved [27].

While a previous UK study attempted to detail forest stakeholders' interests in different ecosystem services [17], gaps in knowledge remain about the delivery of ecosystem services by the growing number of CWGs, and how their integration with different types of networks influence their delivery. This research sets out to explore three questions in an attempt to address these gaps: 
(1) What ecosystem services do CWGs strive to deliver?

(2) To what extent are CWGs part of networks, and what are the characteristics of these networks?

(3) How is a CWG's capacity to deliver ecosystem services influenced by its networks?

\section{Materials and Methods}

A sampling frame was constructed using the websites of CWGs' principal national networks, i.e., the Woodland Trust's Community Woodland Network (England), the Community Woodlands Association (Scotland) and Llais y Goedwig (Wales). A purposive sample was selected on the basis of location, size of woodland managed, and type of CWG. As a matter of courtesy, we were cautious not to include those CWGs repeatedly featured in previous studies. CWGs were contacted via email or telephone as a means of introducing the study, and to identify the individual(s) most knowledgeable about the CWG's site, history, governance, management objectives, activities, and drivers of activities (formal and informal mechanisms including networks and sources of information). These individuals were subsequently invited to participate in a semi-structured interview. Following a number of non-responses and substitutions, 12 interviews relating to 11 CWGs were conducted in $2017 / 2018$.

In the first instance, we attempted to carry out interviews in-person at the woodland site. Where this proved impractical, we resorted to a telephone interview. Interviews typically lasted 45-60 min. All were digitally recorded and transcribed verbatim. In addition, we included management plans and other supporting documents referencing activities and objectives. This allowed for an exploratory, yet in-depth, study of eleven diverse sites, seven of which are based in England, three in Scotland and two in Wales. The size of the CWG sites range from a single hectare to 283 hectares (mean 55, SD 83). All but one of the CWGs reported having a formal management plan at some point in time. However, in some cases the plans had not been updated, either as a result of reduced support and resources, or due to a perceived lack of need owing to unchanging objectives and activities. Related documentation attained for each CWG is included in Table 1, which summarises the sample characteristics.

All transcripts and supporting documentation (totalling 26 sources) were compiled in NVivo where summative content analysis was carried out. This approach was deemed preferable to other means of content analysis given that the research questions relate to established frameworks with predefined components able to serve as a coding framework $[35,36]$. Specifically, we used frameworks relating to: (i) ecosystem goods and services, and (ii) networks. The coding framework pertaining to ecosystem goods and services was derived from the UK National Ecosystem Assessment (UKNEA) and its follow-on (NEAFO) (see Table 2), with each reference segment (passage of text) in a source coded to the most appropriate NVivo node(s) [37]. Given that the terminology around ecosystem goods and services are often absent from the lexicon of non-academics and policymakers, at times it was necessary for these to be inferred from statements on management objectives and activities (as described by Raum et al., 2018 [15]). For instances where the text referred to one or more of the themes in the coding framework (e.g., a single activity pertaining to both a provisioning and cultural service) the passage was coded to all relevant nodes, i.e., cross-coded. 
Table 1. Community Woodland Group Sample Characteristics.

\begin{tabular}{|c|c|c|c|c|}
\hline CWG ID & $\begin{array}{l}\text { Location } \\
\text { (Country) }\end{array}$ & $\begin{array}{l}\text { Size } \\
\text { (ha) }\end{array}$ & Site Ownership and Management & $\begin{array}{l}\text { Management Documents } \\
\text { (Included in Analysis with } \\
\text { Interview Transcripts) }\end{array}$ \\
\hline 1 & England & 6 & $\begin{array}{l}\text { Owned by a Wildlife Trust, managed by a } \\
\text { constituted volunteer group }\end{array}$ & Management plan \\
\hline 2 & England & 4 & $\begin{array}{l}\text { Privately owned, managed as a 'woodland } \\
\text { shelter' by a family in residence }\end{array}$ & Website text on management \\
\hline 3 & England & 140 & $\begin{array}{l}\text { Owned by a local authority, managed by a } \\
\text { 'Friends' group who collaborate with the } \\
\text { authorities' Parks and Countryside Service. }\end{array}$ & Management plan \\
\hline 4 & England & 1 & $\begin{array}{l}\text { Owned and managed by a school (and former } \\
\text { staff) following gifting from the Local Authority. } \\
\text { Access by arrangement. }\end{array}$ & $\begin{array}{l}\text { Local Authority discussion draft } \\
\text { document with objectives }\end{array}$ \\
\hline 5 & England & 16 & $\begin{array}{c}\text { Owned by the Woodland Trust, managed by a } \\
\text { volunteer group }\end{array}$ & Management plan \\
\hline 6 & England & 12 & $\begin{array}{c}\text { Owned by a Wildlife Trust, managed by a } \\
\text { partnership on behalf of a parish council who } \\
\text { lease for a peppercorn sum }\end{array}$ & $\begin{array}{l}\text { Website text on management and } \\
\text { site info leaflet }\end{array}$ \\
\hline 7 & Scotland & 8 & $\begin{array}{c}\text { Owned and managed by the CWG following } \\
\text { purchase from a private seller }\end{array}$ & Articles of association \\
\hline 8 & Scotland & 283 & $\begin{array}{c}\text { Owned and managed by the CWG following } \\
\text { purchase from the Forestry Commission }\end{array}$ & $\begin{array}{c}\text { Articles of association and vision } \\
\text { document }\end{array}$ \\
\hline 9 & Scotland & 85 & $\begin{array}{l}\text { Owned and managed by the CWG following } \\
\text { purchase from a private seller }\end{array}$ & Forest Research case study report \\
\hline 10 & Wales & 40 & $\begin{array}{l}\text { CWG manages on a leasehold basis with } \\
\text { freeholders dictating management for } \\
\text { 'forestry purposes' }\end{array}$ & $\begin{array}{l}\text { Website text on networks and } \\
\text { funds, and Forest Research case } \\
\text { study report }\end{array}$ \\
\hline 11 & Wales & 7 & $\begin{array}{l}\text { CWG own and manage the site, having formed } \\
\text { to acquire it from a private estate }\end{array}$ & Past management plan \\
\hline
\end{tabular}

Table 2. Ecosystem Services from Wooded Environments.

\begin{tabular}{ll}
\hline Ecosystem Service & Examples \\
\hline \multirow{3}{*}{ Provisioning } & Non-timber forest products e.g. crops, livestock and fisheries \\
& Trees for timber \\
& Trees for bio/wood fuel \\
& Woodlands and water supply \\
\hline \multirow{3}{*}{ Regulating } & Climate regulation e.g. shade, shelter, carbon sequestration \\
& Hazard mitigation e.g. flooding, \\
& Pest and disease management \\
& Detoxification and purification of air/soil and water \\
& Pollination \\
\hline Cultural & Recreation and tourism \\
& Food and drink of local provenance \\
& Local festivals/social gatherings \\
& Identities: belonging, sense of place, rootedness, spirituality \\
& Experiences: tranquillity, inspiration, escape, discovery \\
& Capabilities: knowledge, health, dexterity, judgement \\
\hline Supporting & Soil formation \\
& Cycling of nutrients, water \& oxygen \\
& Biodiversity \\
\hline
\end{tabular}


To explore the characteristics of the networks referred to, we drew on an established typology of British woodland owners [24] which outlines three types of networks, related to:

- $\quad$ woodland management approach and associated institutions, i.e., organisations and institutions whose missions closely match the CWGs' objectives and values;

- networks related to place, comprising others in the immediate locality of the woodland or its manager(s);

- networks by social and personal identity, made up of friends, neighbours, and others reflecting the social connections, demography and personal values and beliefs of those managing the CWG.

Such information was ascertained through responses to a series of questions in the interviews which explored the CWGs' connections and the respective contributions and benefits. As with the coding of ecosystem goods and services, cross-coding was undertaken for the few instances where a connection spanned two or more of the network types (e.g., a relative in an organisation with a role in providing woodland management guidance).

Counts of each CWGs' networks and ecosystem services were derived using a manual coding process whereby text was assigned to nodes reflecting the elements of the aforementioned frameworks. Given the challenge of distinguishing unique activities and relationships over space, time and sources (e.g., multiple documents), we opted to code the number of instances interviewees and documents referenced the different networks and ecosystem services, as oppose to attempting to supposing the number of unique ecosystem services delivered on the ground, and networks associated with the sites and organisations. Thus, our counts do not attempt to definitively measure CWGs' ecosystem services and networks, but rather provide a proxy for the importance CWGs ascribe to the different types of each, based on the activities and relationships described by the respondents and documents. This approach allowed us to determine what individual CWGs consider to be important and where they focus their efforts, and to explore variation across the sample. To ensure adequate rigour and replicability in the analysis we followed the primary steps outlined by Hruschka et al. (2004) [37]. This involved three researchers independently piloting the coding process on the same three sample transcripts, identifying areas of uncertainty and disagreement, and resolving these through disambiguation until an acceptable level of intercoder reliability resulted (Cohen's Kappa $>0.7$, as described in Lombard et al., 2002 [40]). At this stage, a single researcher coded the remaining sources using the agreed framework.

\section{Results}

\subsection{Ecosystem Services}

In terms of the four broad ecosystem services, 520 references were identified and coded for the sample as a whole. These comprised $258(49.6 \%)$ references to cultural services, $130(25.0 \%)$ to supporting services, $72(13.8 \%)$ to provisioning services and $60(11.5 \%)$ to regulating services. While factors, such as a CWG's lifespan and the amount of documentation available for coding, contribute to the variation in the respective number of ecosystem service references, consideration of the proportional share clearly demonstrates the importance of cultural ecosystem services to all of the CWGs featured (Figure 1). In contrast, references to other services are more varied, reflecting the differing levels of focus CWGs give to non-cultural ecosystem services. 


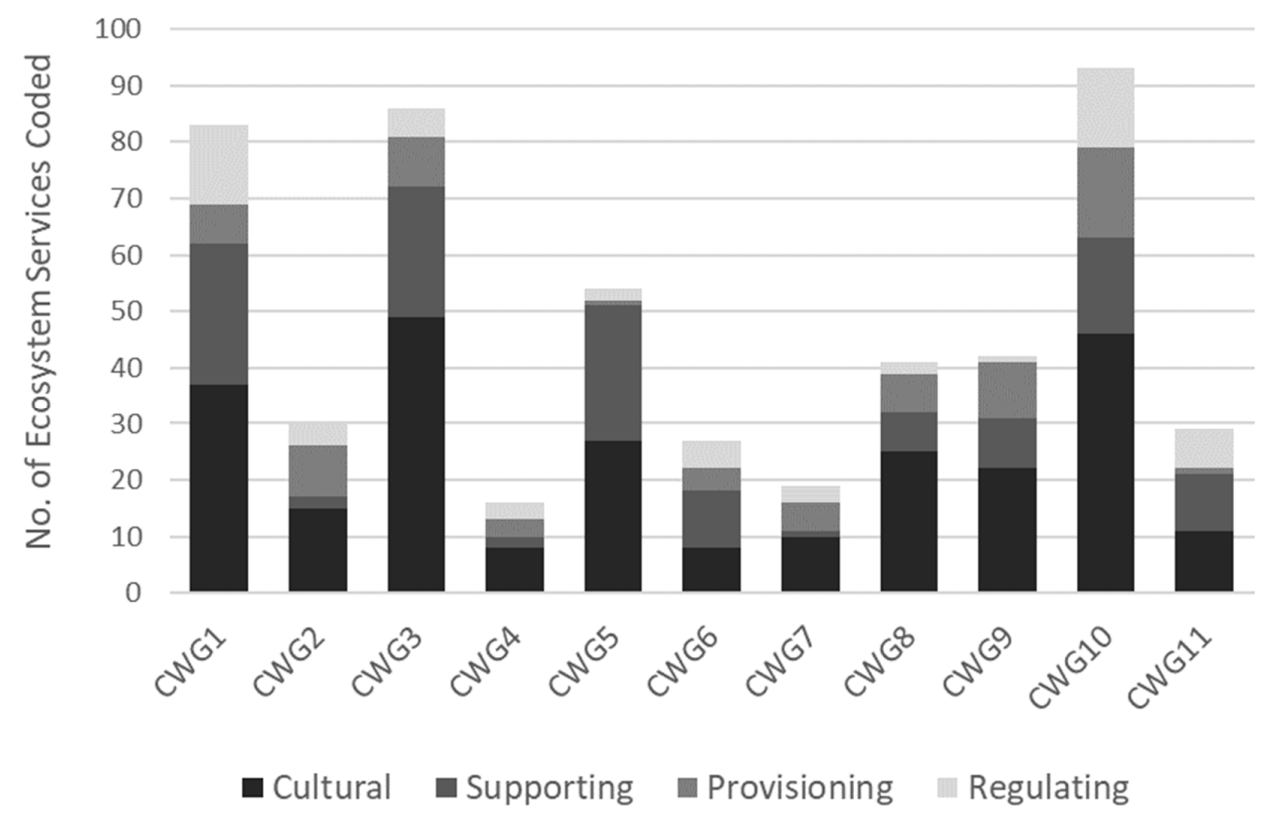

Figure 1. Count of Ecosystem Services Referenced by CWGs.

While many of the references for cultural ecosystem services reflect multiple goods and benefits, the provision of access for the purposes of recreation, relaxation and education proved particularly common. Similarly, the CWGs routinely serve as a space for gatherings to promote social connectedness and fun (e.g., organised barbeques). Additionally, CWGs collectively organise and facilitate events through which the community can acquire skills and knowledge (bushcraft, wood processing, first aid, forest schools, etc.). While the CWGs themselves seldom employ staff, involvement with the groups and activities offer opportunities to improve employability and develop skills. Furthermore, CWG sites periodically assist local businesses in need of outdoor space or natural resources. As well as actively organising activities related to cultural ecosystem services, CWGs often reported managing sites in a way that preserves or enhances a sense of place for the community. This has involved improving a site's aesthetics, as well as preserving historical and cultural features, including archaeological and industrial remnants considered important to local heritage.

References relating to supporting services were dominated by CWGs' aims to preserve or enhance their sites' biodiversity. As well as a tendency for planting native trees, the CWGs referenced their management of habitats, including ponds, heathland and bog, to meet biodiversity objectives. In some cases, the CWG's area encompassed designated sites, such as ancient woodland, Local Nature Reserves (LNRs) and Sites of Special Scientific Interest (SSSIs), with a number of protected species present (both aquatic and terrestrial). In addition to habitat creation and management, the CWGs also reported instances of recording and monitoring biological indicators. For some groups this is accomplished through their own informal ecology groups, while others collaborate with external groups and institutions. Notably, nine of the CWGs described how misuse or overuse of the site undermined efforts to protect or enhance biodiversity, highlighting a challenge of balancing cultural service provision with the supporting service of biodiversity. Common issues include: littering and fly tipping, vandalism, tree felling/removal, erosion, disturbance, poaching, dog and human excrement, and straying from paths.

I get fed up with people saying, "oh, access is absolutely brilliant, think of all the great wellbeing things that you're producing for people, and blah, blah, blah, blah, blah, and more people is always necessarily a better thing" [ . . ] but if I could show you photographs of what this woodland looked like before we let people in and what it looks like now, there is actually real damage happening here. (CWG 12) 
Provisioning services referenced by the CWGs included small-scale timber harvesting and processing, but more typically provisions related to non-timber forest products, such as coppiced wood, biofuel and charcoal, mushrooms, and fruits produced from orchards. Although some of the larger CWGs consider traditional forestry integral to their management and funding, for others the products their sites provide are insufficient to fund the groups' ambitions. Instead, goods derived from the sites typically provide intermittent income (sales of Christmas trees and fire logs) or serve as recompense for volunteers' contributions.

Regulating services referred to typically related to those delivered by the CWGs personnel as oppose to those implicit with the presence of trees and vegetation, yet regulation of climatic conditions through the provision of shelter and shade did feature. More commonly, CWGs noted their regulation of pests and diseases through their planting choices and control activities in relation to ash dieback, phytophthora ramorum and rhododendron. Several CWGs also referred to management of hazards to the public including dealing with precarious branches and steep-sided embankments. One CWG also referred to their beekeeping reflecting regulation of pollination.

\subsection{CWG Networks}

Analysis revealed a total of 381 references related to the CWGs' networks. Of these, $183(48.0 \%)$ reflect place-based networks, $159(41.8 \%)$ reflect management approach networks, and $39(10.2 \%)$ reflect social networks (Figure 2).

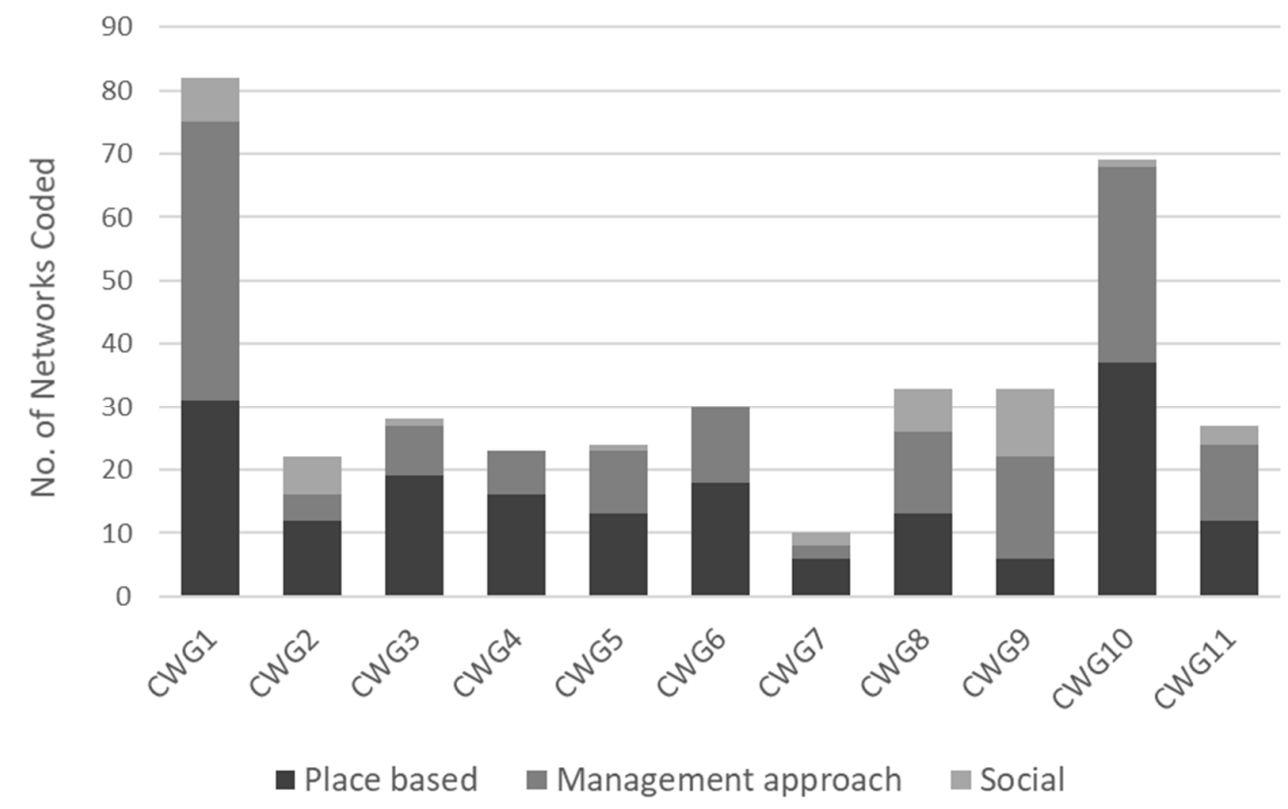

Figure 2. Count of Networks Referenced by CWGs.

In many cases place-based networks encompassed other local groups making use of the site, such as schools, church groups and scouts. Some groups also recounted instances of connecting and collaborating with individuals with a specialism who could offer advice or a service, including, for example, a local hydrologist. In addition, all of the groups described instances in which activities had been carried out by volunteers. Some of the volunteers were said to be members of the CWG, while others held no attachment, but instead had ties to a separate organisation or group which provides volunteering opportunities across various sites and projects. In both cases, volunteers (and members) were typically based in close proximity to the respective CWG site.

Actors in management approach networks included The Forestry Commission, The Borders Forest Trust, The Woodland Trust, Natural England, Wildlife Trusts, The Community Woodlands Association, other CWGs, and individual Local Authority staff, such as tree officers and wildlife officers. Six of the CWGs referenced the assistance they had 
received from their management approach networks in establishing a formal management plan for their respective site.

We drew up a management plan with the Forestry Commission five years ago. (CWG 2)

The original plan was written for us by the Wildlife Trust. We've since revived it in keeping with the Forestry Commissions' own guidelines on woodland management. (CWG 6)

Social networks encompassed friends, neighbours, and other people reflecting land managers' own social connections, demography and personal values and beliefs. Examples of 'other people' unearthed through the research include family and former colleagues with a role relevant to woodland management. Although some of these individuals are also part of place-based and management approach networks, they have the distinction of being approached or involved specifically because of a personal connection to someone involved in running the respective CWG.

\subsection{Networks and Ecosystem Service Delivery}

Place-based networks were frequently referenced in relation to the provision of labour. In this respect, their contribution to the delivery of ecosystem services is typically direct and tangible. For example, volunteers within the local community are often involved in activities, such as site maintenance to improve the aesthetics and accessibility of a site (i.e., environmental settings under the umbrella of cultural services). Place-based networks were also occasionally noted to facilitate such tasks through the provision of equipment. Owing to the time and effort involved in carrying out practical tasks, several interviewees commented that their connectedness to local networks is essential. By extension, the presence, extent or quality of the associated ecosystem services also tend to be heavily dependent on an established place-based network.

They [volunteers] do most of the work there. And realistically, beyond the odd bit of tree surgery, they are the ones who are best placed to do most of the work in the wood; we can't get big machines in there. (CWG 5)

Our main purpose was to engage the children, and that was a key reason why we wanted a pond as well [ ... ] The pond was created by TCV (The Conservation Volunteers), even the digging of the pond was exciting to the children and the local fire brigade came down and filled it in. (CWG 4)

The golf course don't use machines in the winter because they wouldn't do the greens a lot of good [so] he has lent us his machines, and we've got two of his tractors at the moment. (CWG 8)

ASDA company sponsored the volunteer hut, which is a converted shipping container... [It] has a small office, a store, a toilet and small kitchen area. This has a big impact on the numbers of people coming to events and wanting to use the woods for events. As soon as there is somewhere to make tea and go for a pee the dynamics change quite considerably. (CWG 10)

In addition to their role in facilitating and carrying out practical tasks, place-based networks were frequently referenced as site users. Such usage by individuals and groups may result in the provision of an ecosystem service, or alternatively, demonstrate the value of CWG sites and events in providing services (typically cultural). For example, several CWGs encourage the use of their sites for education, either linking to established curriculums or through hosting events which take advantage of the site's natural resources, such as training in woodcraft and outdoor survival. The local networks also help to demonstrate CWGs value as a resource for recreation and health and wellbeing. As well as offering a venue for informal physical activities, such as walking, there is evidence of CWGs providing opportunities to restore mental health. The hosting of Branching Out-an outdoor activity programme pioneered by Forestry Commission Scotland (now Scottish 
Forestry) and the National Health Service Scotland which is available to adults who use mental health services-is one such example.

We have a forest school three times a week and a lot of the local school children will come to that. We have local churches coming around and then we have a lot of courses so we have people coming for bushcraft or willow weaving. (CWG 2)

We have had the high school, kids that were attending the John Muir Award - which is learning difficulties kids-they come once a year. They stay in the cabin overnight and they build a fire [... ] We've got a lot of dog walkers come. The 'Walking to Health' group come and they're a fitness lot that the government is trying to encourage, and Lisa [... ] she has assistants from the NHS and I think mental support, and she brings people with depression and things and 'Branching Out', and she takes them out. (CWG 9)

We do work with the local school and have forest days up here with them. And we have sort of picnics. We do have forest walks, which we take people show them the way round the forest. We have been doing that regularly. We did have a barbecue where everyone's invited, have a bit of music and work on as many people as possible. (CWG 8)

Management approach networks were found to be particularly useful in providing CWGs with the advice and resources needed to realise their aims, whether via support with management plans, practical woodland management advice, or through assistance in identifying and attaining funding and materials. In some instances, there is a distinct connection between an interaction with the network and the delivery of a particular ecosystem good or service. However, in other cases the networks help to build knowledge or inspire, eventually playing some part in the delivery of a single or suite of ecosystem goods and services. In such cases it can be difficult even for those managing the sites to disentangle the relative role the network had in arriving at a decision or enacting the subsequent delivery. Similarly, there are instances in which an ecosystem service or good may already be present, though is being enhanced or grown owing to interaction with those within management approach networks. Measuring the relative importance of the management approach network is also complicated by the fact that the mechanisms by which knowledge exchange occurs between CWGs and those in the network is highly variable; sometimes specific requests for information are made, while at other times information is inadvertently absorbed through attendance at events or through alerts and updates the CWG has opted into. Thus, while the role of management approach networks in a CWG's provision of ecosystem services is often difficult to quantify, it is nevertheless clear that they are extremely valuable in allowing CWGs to establish and subsequently pursue their respective management objectives.

We work with Natural England on a lot of our woods as a lot of them are SSSIs, so we get a flow of information from them through their woodland advisors. From Natural England we are currently making changes in terms of species composition to some of our woods in relation ash dieback. (CWG 1)

We have had two lots of trees from the Woodland Trust. We got a Jubilee plantation, which was about 40 young saplings, and then I think we've had two other lots from the Woodland Trust. (CWG 9)

Once per month we do a road trip to another community [ ... ] we would go to somewhere similar and look what they are doing and talk to them and you normally meet some amazing experts [... ] who would tell you about this and that. So, there is this kind of constant knowledge seeping in. (CWG 2)

I had Forest Research come up because I have a problem with sweet chestnut in here; they were dying off $[\ldots]$ also we are corporate members of the Arb. Association so that keeps us up to date with all the relevant [pest and disease] information. (CWG 3)

Contributions from social networks to ecosystem service delivery proved less prevalent across the sample. Moreover, the nature of the contributions is more variable than 
from actors of other network types. Social connections may have no specific duty to advise or assist CWGs in the same way that formal organisations typically found within management approach networks are often obliged to do. In addition, these connections are not necessarily locally based, in which case site visits and participation in practical tasks or engagement in recreational pursuits can be infeasible. While such factors may limit the scope and frequency of social networks assisting in ecosystem service delivery, CWGs did identify a number of individuals relevant to woodland management, as well as examples of how social networks had at times shaped management objectives and site characteristics.

The first year we were here we got in touch with about twenty people we either knew or were friends of friends, environmental companies, social enterprises of friends who had woodlands, [name removed] the Forestry Commission man here. So we had about two dozen people who came round and gave advice. (CWG 2)

I had contacts in the private forestry sector from my historical work, I have contacts at the moment through the sites I manage and personal interest. (CWG 5)

My sons both went through university in Edinburgh, and one is in wildlife and the other is in forestry. My son's been good, because before he used to go and say, you need to do this, you need to do that. He would go in and do a bit of pruning. (CWG 9)

Given the often ad-hoc and inconsistent involvement, the value of social networks to CWGs is difficult to generalise; contributions may be infrequent yet extremely important, or readily available yet superfluous. Where these connections are local, able to assist with management approaches, and committed, they are likely to form part of the CWG's management team, for example, as a director or member of a steering committee. By amassing several such individuals, CWGs enhance their own institutional (or internal) capacity to deliver ecosystem services, and as a result, may become less reliant on management approach networks.

Well I'm a forester. My husband is a wildlife specialist. The other member of our board is an arboriculture company. One of our people who does an awful lot of volunteering for us has done a PhD on bats. We've got an ex-professor of botany. We've got three people with forestry PhDs in the group. (CWG 11)

The members are coming in from other backgrounds, meteorological backgrounds, ecological backgrounds and things like that, so they are obviously members of other organisations and societies, and they bring that into the discussions that we have. So, we're not going out to seek information or advice, but people are liaising indirectly with these other folks, and they're bringing it back into the discussions. (CWG 7)

\section{Discussion}

\subsection{Ecosystem Service Delivery by CWGs}

Our findings demonstrate that the CWGs have an inclination for the delivery of cultural services. In practice, this often involves organising and hosting social gatherings, creating and maintaining access, providing a space for recreation and relaxation, and offering opportunities for education and training. As may be expected, CWGs typically aim to provide these services first and foremost for the local community. While this implies that CWGs are limited in scope, their potential to provide cultural services to communities who may otherwise be without is a notable benefit. Provision of such benefits is likely to be greatest when CWGs are most accessible (e.g., close to urban communities), since woodlands close to many homes tend to experience greater use [41,42]. Moreover, although some CWGs are of modest size, there is evidence to suggest that even 2 ha woodlands are sufficient to attract regular recreational visits by all age groups [43].

The environmental settings overseen by CWGs can also promote health and wellbeing benefits; not only do woodlands provide a space to enact 'green exercise', the contact with nature inherent in these activities can assist in sustaining motivation and enhance participants' results $[44,45]$. As well as physical benefits, woodland settings are gaining 
recognition for their provision of restorative and mental health benefits [46] leading some health services to prescribe time in woodlands as a means of treatment (as reported by O'Brien et al., 2006 [47]; Willis et al., 2016 [48]). Although only one CWG from our sample referred to hosting formal activities to improve wellbeing, CWGs' ambitions to create and improve access can be assumed to facilitate a range of physical and mental health benefits, albeit in a manner that is typically informal and unmeasured. Moreover, such benefits have been found to be enhanced in aesthetically pleasing environmental settings [49-51]-something which many CWGs in our sample sought to create (for example, via increasing landscape diversity and tending to footpaths). Similarly, CWGs offer a rich sensory environment for learning and training which is often more appealing and enjoyable than traditional indoor settings [52]. Thus, CWGs offer a plethora of cultural services and opportunities which can be contrasted with private ownership. As one respondent remarked:

"[Community woodlands] allow the community to get involved. If it's private you might have permission to walk through it but not anything else." (CWG 2)

Although CWGs are capable of providing a range of cultural benefits, like any manager of natural resources, their decisions and activities come with trade-offs [53]. The pursuit of cultural services through the promotion of easy access and high footfall —as with many of our CWG sample - can introduce damage and disturbance to the detriment of other ecosystem services $[54,55]$. Activities designed to enhance biodiversity, such as native tree planting and the creation of ponds, bogs and glades, are perceived as being particularly susceptible to impacts from site misuse and overuse. Given that many of our CWGs describe both biodiversity (a supporting service) and cultural benefits to the community (particularly access) as being central to their aims, their ability to be holistically successful is inherently difficult. As alluded to, such challenges and trade-offs are not unique to CWGs. Quine et al. (2007) [56] notes that operations that are beneficial to species and habitats of high conservation priority may become uneconomic, and thus abandoned, as markets change. In such circumstances, the continuation of the conservation-friendly operations may be contingent on grant funding or access to markets (through certification schemes). Thinning, which alters canopy composition, the microenvironment and ground flora composition, often stimulating increased biodiversity [57], is one such operation. However, Quine et al. (2007) [56] reported that between $55 \%$ and $80 \%$ of the plantation forests in Scotland remained unthinned, possibly owing to the lack of commercial value of the produce in early thinnings, and the net cost of the operations [58]. In contrast, CWGs can be well placed to carry out these uneconomical yet conservation-friendly tasks, and eight of the CWGs in our sample referred to coppicing or thinning their woodlandsalthough in some cases, the rationale for these operations was to improve cultural (access and user experience) and regulating services (hazard mitigation/user safety), rather than to specifically enhance biodiversity. Nevertheless, it is clear that CWGs often have a commitment to protecting and enhancing biodiversity, regardless of market conditions and social challenges.

In contrast to the FAO's 'community forests' - defined in part by an objective to manage forests for food, fuel, essential goods and income [59]—our sample of British-based CWGs tend not to place the same emphasis on provisioning services or rural development, nor are they subservient to markets to the extent of commercially managed forests. However, provisioning services were frequently evidenced by our CWGs, whether in relation to timber processing, wood fuel or harvesting of non-forest timber products, such as fruit and fungi. The income generated through these activities is often modest, yet at times it is vital to sustaining a group and allowing other services and activities to be provided via reinvestment. While such circumstances may be perceived as a limitation of CWGs, it is worth noting that a recent study into the economic benefit of woodlands concluded that the benefits generated through activities relating to health and wellbeing and recreation outweigh those from goods and services with a market value [60]. In other words, for CWGs in pursuit of multiple benefits, including cultural services, their total economic value 
(per unit area) may be greater and more far-reaching than those of woodlands managed primarily for provisioning goods and services, such as saleable timber.

In addition to trade-offs, which imply the loss or limiting of some services, forests can provide multiple unintended or unrealised benefits, even if managed primarily for a particular service, such as timber production [61]. Based on our findings, we suggest that this assertion may be particularly true for regulating services, such as climate (carbon sequestration), detoxification and purification, and pollination. Such services were seldom articulated in management objectives or descriptions of the CWGs' activities, yet this is not to say that the benefits were absent. Instead, we posit that these serviceswhich are undoubtedly grown or enhanced through CWGs' routine activities, such as tree planting [62] - are either not fully appreciated or deemed too obvious to mention. While mapping and modelling approaches are needed to more accurately compare delivery of regulating services from site to site (and with owner objective) [63,64], we can at least conclude that when it comes to the management objectives and activities of the CWGs, regulating services were rarely the focus.

\subsection{The Importance of Networks}

Pollard and Tidey (2009) [27] noted that although CWGs are often members of networks, in many cases this does not equate to active involvement. Through this study we have attempted to uncover examples of meaningful engagement and support, and specifically explore the extent to which different types of network contribute to CWGs' delivery of ecosystem services.

While past research has described the difficulty CWGs can experience in accessing useful contacts, such as woodland officers [33], their engagement with wider management approach networks was found to be commonplace. In fact, many CWGs appear to rely on management approach networks to some degree, with around half of our sample having received assistance from such networks when establishing management plans for their woodlands. This is reflective of the role that management approach networks typically play in CWGs delivery of ecosystem services, in that they equip CWGs through sharing expertise and resources though are rarely involved in practical activities on the ground. Advice relating to species selection and the provision of saplings for planting are prime examples of the support that management approach networks can offer. While the range and extent of the impact such support has on the delivery of ecosystem services may not be readily presented by representatives of CWGs, it is clear that it does help to grow or enhance this delivery. In the example given, management approach networks' support of tree planting assists with regulating and supporting services, even if the CWGs' desires to plant are aligned with objectives to improve user experiences through enhancing aesthetics or to create habitat so as to increase biodiversity. Management approach networks also supply advice around the mitigation of threats and help to inform on how management can be adapted should threats materialise-most notably in relation to pests and diseases and climate change. The knowledge and skills offered through management approach networks relate not only to woodland management but also to issues, such as group development, accessing funding and business management [29], without which, attempts to develop enterprise activities may prove futile [31]. Thus, while the support of management approach networks may not relate directly to a particular ecosystem service, through accessing resources and acting on the advice that these networks offer, CWGs increase the resilience and sustainability of themselves and their sites [18], helping to secure ongoing delivery of a suite of ecosystem services.

Place-based networks may also contribute to knowledge sharing, including practical information (as described by Kueper et al., 2013 [65]) which has been shown to be indemand among CWGs [33]. In practice this includes, for example, visiting other local community managed sites to witness and learn about new approaches and techniques. In addition, others in local networks, including land managers, are known to share equipment and machinery $[16,33]$, allowing CWGs to improve their sites' infrastructure and ecological 
resources while minimising expenditure. Local businesses looking to fund local social and environmental projects, as part of corporate responsibility, can also prove extremely valuable in this regard. Despite the obvious value of place-based networks brought about through sharing of knowledge, equipment and financial resources, perhaps their biggest strength is the labour provided by local volunteers. The roles of volunteers in forest settings can include conservation, trail maintenance, biological monitoring and recording, and reporting of problems [66]. Volunteers are also frequently involved in organising events and activities which can help to attract those who rarely visit woodlands, enabling them to realise benefits which may otherwise be deemed unobtainable [67-69]. Not only are place-based actors, such as volunteers, an asset in ecosystem delivery, they are frequently the recipients of benefits as a result of their ties to a CWG and its site. Cultural services, such as a sense of belonging, connectedness to nature and other people, improvements to physical and mental health, and education, are commonly cited benefits associated with woodland settings [67-69], though benefits from provisioning and regulating services are also possible (access to forest products, improved air quality etc.).

In contrast to management approach networks and placed-based networks, social networks were comparatively small and rarely used by our CWGs. Moreover, their lack of defining attributes and activities make it unfeasible to relate their contributions to a particular type of ecosystem service. While social networks occasionally do provide valuable contributions to CWGs, in practice they may be coerced into becoming part of the group itself either as a generic member or as a committee member. In doing so, their skills and knowledge may affect the type of management undertaken or the degree of ambition in the group's woodland management objectives. Through such involvement, group members may find opportunities to enhance their own technical and practical skills in areas, including woodland management, group development, grant capture and business management [29].

\section{Conclusions}

During recent periods of austerity, the transfer of public land ownership and management responsibilities to community groups has become a familiar occurrence [30]. As a result, community forestry has become increasingly important for ecosystem service delivery. While large-scale community forestry represented in international studies tends to strive for livelihood benefits, this research reaffirms that the aims of Britain's CWGs appear more commonly related to protection of land for environmental, biodiversity and public amenity value [27], i.e., supporting and cultural services. Given that such benefits are increasingly emphasised in forest policy agendas [70], it is clear that from a policy perspective at least, CWGs represent a promising model for ecosystem service delivery. Research highlighting the tendency of ill-equipped Local Authorities to perceive trees as a liability as opposed to an asset [71], as well as that reporting a lack of active management among private woodland owners [61], lends further credence to the notion that CWGs should be viewed as a credible option for woodland management. However, CWGs' ability to deliver ecosystem services may be constrained by overuse and misuse of sites, as well as limited financial resources, management expertise, labour, and freedom to act or manage around particular objectives (for example, if the site has a separate owner). Since CWGs are also impacted by austerity (increased competition for reduced funding) it may be necessary to address challenges through informal mechanisms, including through the support of networks. Thus, while there is some indication that a locally led approach intrinsic to CWGs can make for more effective management than that administered by the state [10], this will likely be conditional on local groups being well connected and supported through their networks. In practice, reliance on networks to deliver ecosystem services among CWGs varies from group to group (partly reflecting differences in internal capacity), yet it is apparent that different types of network recurrently provide particular forms of assistance. Not only do these networks collectively assist in delivering the ecosystem services CWGs aspire to provide, they may also offer a solution to disputes with local communities, 
site misuse, a lack of resources and internal conflicts [72]. In light of these benefits, we conclude that efforts to strengthen and grow relationships across all network types can prove worthwhile, regardless of a CWG's existing internal capacity.

Author Contributions: Conceptualisation, M.D., B.A.-O. and L.O.; methodology, M.D., B.A.-O. and L.O.; formal analysis, M.D.; writing—original draft preparation, M.D.; writing—review and editing, B.A.-O. and L.O. All authors have read and agreed to the published version of the manuscript.

Funding: This research was funded by the Forestry Commission under the Science and Innovation Strategy for Forestry in Great Britain.

Data Availability Statement: The manuscript is based on verbatim transcripts which hint at the participant's identities. Given assurances about anonymity the transcripts have not been included as Supplementary Materials.

Conflicts of Interest: The authors declare no conflict of interest.

\section{References}

1. Sarukhán, J.; Whyte, A.; Hassan, R.; Scholes, R.; Ash, N.; Carpenter, S.T.; Pingali, P.L.; Bennett, E.M.; Zurek, M.B.; Chopra, K.; et al. Millenium Ecosystem Assessment: Ecosystems and Human Well-Being; Island Press: Washington, DC, USA, 2005. Available online: https:/ / agris.fao.org/agris-search/search.do?recordID=XF2006408644 (accessed on 22 November 2021).

2. Helms, J.A. Forest, forestry, forester: What do these terms mean? J. For. 2002, 100, 15-19.

3. Behan, R.W. Multiresource forest management: A paradigmatic challenge to professional forestry. J. For. 1990, 88, 12-18.

4. Bengston, D.N. Changing forest values and ecosystem management. Soc. Nat. Resour. 1994, 7, 515-533. [CrossRef]

5. Mather, A.S. Forests of consumption: Postproductivism, postmaterialism, and the postindustrial forest. Environ. Plan. C Gov. Policy 2001, 19, 249-268. [CrossRef]

6. Wiersum, K.F. 200 years of sustainability in forestry: Lessons from history. Environ. Manag. 1995, 19, 321-329. [CrossRef]

7. Agrawal, A.; Chhatre, A.; Hardin, R. Changing governance of the world's forests. Science 2008, 320, 1460-1462. [CrossRef] [PubMed]

8. Cronkleton, P.; Taylor, P.L.; Barry, D.; Stone-Jovicich, S.; Schmink, M. Environmental Governance and the Emergence of Forest-Based Social Movements; CIFOR: Bogor, Indonesia, 2008.

9. Hajjar, R.; Oldekop, J. Research frontiers in community forest management. Curr. Opin. Environ. Sustain. 2018, 32, 119-125. [CrossRef]

10. Behera, B. Explaining the performance of state-community joint forest management in India. Ecol. Econ. 2009, 69, 177-185. [CrossRef]

11. Bowler, D.E.; Buyung-Ali, L.M.; Healey, J.R.; Jones, J.P.; Knight, T.M.; Pullin, A.S. Does community forest management provide global environmental benefits and improve local welfare? Front. Ecol. Environ. 2012, 10, 29-36. [CrossRef]

12. Folke, C.; Cundill, G.; Queiroz, C. Communities, ecosystems and livelihoods. In Ecosystems and Human Well-Being: Multiscale Assessments; Capistrano, D., Samper, C., Lee, M., Raudsepp-Hearne, C., Eds.; Island Press: Washington, DC, USA, 2005; Volume 4, pp. 261-277. Available online: https:/ / citeseerx.ist.psu.edu/viewdoc/download?doi=10.1.1.353.5740\&rep=rep1\&type=pdf (accessed on 22 November 2021).

13. Ostrom, E. Reformulating the commons. Swiss Political Sci. Rev. 2000, 6, 29-52. [CrossRef]

14. Arts, B.; de Koning, J. Community forest management: An assessment and explanation of its performance through QCA. World Dev. 2017, 96, 315-325. [CrossRef]

15. Raum, S. A framework for integrating systematic stakeholder analysis in ecosystem services research: Stakeholder mapping for forest ecosystem services in the UK. Ecosyst. Serv. 2018, 29, 170-184. [CrossRef]

16. Fabricius, C.; Folke, C.; Cundill, G.; Schultz, L. Powerless spectators, coping actors, and adaptive co-managers: A synthesis of the role of communities in ecosystem management. Ecol. Soc. 2007, 12. [CrossRef]

17. Olsson, P.; Gunderson, L.H.; Carpenter, S.R.; Ryan, P.; Lebel, L.; Folke, C.; Holling, C.S. Shooting the Rapids: Navigating Transitions to Adaptive Governance of Social-Ecological Systems. Ecol. Soc. 2006, 11, 18. [CrossRef]

18. Gibson, C.C.; McKean, M.A.; Ostrom, E. (Eds.) People and Forests: Communities, Institutions, and Governance; MIT Press: Cambridge, MA, USA, 2000.

19. Saxena, G. Relationships, networks and the learning regions: Case evidence from the Peak District National Park. Tour. Manag. 2005, 26, 277-289. [CrossRef]

20. Borgatti, S.; Cross, R. A relational view of information seeking and learning in social networks. Manag. Sci. 2003, 49, 432-445. [CrossRef]

21. Lauber, T.B.; Decker, D.J.; Knuth, B.A. Social networks and community-based natural resource management. Environ. Manag. 2008, 42, 677-687. [CrossRef]

22. Cloke, P.; Marsden, T.; Mooney, P. The Handbook of Rural Studies; SAGE Publications, Inc.: New York, NY, USA, 2006. 
23. Parkins, J.R.; Dunn, M.; Reed, M.G.; Sinclair, A.J. Forest governance as neoliberal strategy: A comparative case study of the Model Forest Program in Canada. J. Rural Stud. 2016, 45, 270-278. [CrossRef]

24. O'Brien, L.; Ambrose-Oji, B.; Hemery, G.; Petrokofsky, G.; Raum, S. Payments for Ecosystem Services, Land Manager Networks and Social Learning; Forest Research: Farnham, UK, 2018.

25. Woodland Trust. Community Ownership for Woodland Management and Creation Research Report; The Woodland Trust: Lincolnshire, $\mathrm{UK}, 2011$.

26. Wavehill. A Survey of Community Woodland Groups in Wales. Report of Main Findings; A Report for Forestry Commission Wales; Wavehill: Bronx, NY, USA, 2010.

27. Pollard, A.; Tidey, P. Community woodlands in England. In Baseline Report for Forest Research; Forest Research: Farnham, UK, 2009.

28. Lawrence, A.; Molteno, S. Community forest governance: A rapid evidence review. In A Report by Forest Research on Behalf of the Independent Panel on Forestry. The Research Agency of the Forestry Commission; Forest Research: Farnham, UK, 2012.

29. Lawrence, A.; Ambrose-Oji, B. A Framework for Sharing Experiences of Community Woodland Groups; Forestry Commission: Mansfield, UK, 2013.

30. Simson, A.J. Urban Greenspace in the UK-Future governance in austere financial times? Mod. Environ. Sci. Eng. 2018, 4, 197-202.

31. Ambrose-Oji, B.; Lawrence, A.; Stewart, A. Community based forest enterprises in Britain: Two organising typologies. For. Policy Econ. 2015, 58, 65-74. [CrossRef]

32. Wilmot, A.; Harris, K. Community Woodland Baseline Report Wales; Forest Research: Farnham, UK, 2009.

33. Ambrose-Oji, B. Community woodlands and community woodland groups in England: Sustainability, networking and voice. In Workshop Synthesis Report. Prepared for Forestry Commission England and Small Woods. The Research Agency of the Forestry Commission; Forestry Commission: Mansfield, UK, 2013.

34. Cundill, G.N.R.; Fabricius, C.; Marti, N. Foghorns to the future: Using knowledge and transdisciplinarity to navigate complex systems. Ecol. Soc. 2005, 10. [CrossRef]

35. Hsieh, H.-F.; Shannon, S.E. Three approaches to qualitative content analysis. Qual. Health Res. 2005, 15, 1277-1288. [CrossRef]

36. Church, S.P.; Dunn, M.; Prokopy, L.S. Benefits to qualitative data quality with multiple coders: Two case studies in multi-coder data analysis. J. Rural Soc. Sci. 2019, 34, 2.

37. Hruschka, D.J.; Schwartz, D.; St. John, D.C.; Picone-Decaro, E.; Jenkins, R.A.; Carey, J.W. Reliability in coding open-ended data: Lessons learned from HIV behavioral research. Field Methods 2004, 16, 307-331. [CrossRef]

38. Watson, R.; Albon, S.; Aspinall, R.; Austen, M.; Bardgett, B.; Bateman, I.; Berry, P.; Bird, W.; Bradbury, R.; Brown, C.; et al. UK National Ecosystem Assessment: Understanding Nature's Value to Society. Synthesis of Key Findings; Information Press: Oxford, UK, 2011.

39. Church, A.; Fish, R.; Haines-Young, R.; Mourato, S.; Tratalos, J.; Stapleton, L.; Willis, C. UK National Ecosystem Assessment Follow-on: Cultural Ecosystem Services and Indicators; UNEP-WCMC LWEC: Cambridge, UK, 2014.

40. Lombard, M.; Snyder-Duch, J.; Bracken, C.C. Content analysis in mass communication: Assessment and reporting of intercoder reliability. Hum. Commun. Res. 2002, 28, 587-604. [CrossRef]

41. Ward Thompson, C.; Aspinall, P.; Bell, S.; Findlay, C.; Wherrett, J.; Travlou, P. Open Space and Social Inclusion: Local Woodland Use in Central Scotland; Forestry Commission: Edinburgh, UK, 2004.

42. Tzoulas, K.; James, P. Peoples' use of, and concerns about, green space networks: A case study of Birchwood, Warrington New Town, UK. Urban For. Urban Green. 2010, 9, 121-128. [CrossRef]

43. Coles, R.; Bussey, S. Urban forest landscapes in the UK-Progressing the social agenda. Landsc. Urban Plan. 2000, 52, 181-188. [CrossRef]

44. Barton, J.; Hine, R.; Pretty, J. The health benefits of walking in greenspaces of high natural and heritage value. J. Integr. Environ. Sci. 2009, 6, 261-278. [CrossRef]

45. Raine, R.; Roberts, A.; Callaghan, L.; Sydenham, Z.; Bannigan, K. Factors affecting sustained engagement in walking for health: A focus group study. Br. J. Occup. Ther. 2016, 80, 183-190. [CrossRef]

46. Christie, M.; Cole, F. The impact of green exercise on volunteers' mental health and well being: Findings from a community project in a woodland setting. J. Ther. Hortic. 2017, 27, 17-33.

47. O'Brien, L.; Greenland, M.; Snowdon, H. Using woodlands and woodland grants to promote public health and wellbeing. Scott. For. 2006, 60, 18-24.

48. Willis, K.; Crabtree, B.; Osman, L.M.; Cathrine, K. Green space and health benefits: A QALY and CEA of a mental health programme. J. Environ. Econ. Policy 2015, 5, 163-180. [CrossRef]

49. Kaplan, G.A. Socioeconomic considerations in the health of urban areas. J. Urban Health 1998, 75, 228-235. [CrossRef]

50. Ode, Å.K.; Fry, G.L. Visual aspects in urban woodland management. Urban For. Urban Green. 2002, 1, 15-24. [CrossRef]

51. Ward Thompson, C.; Aspinall, P.; Bell, S.; Findlay, C. "It gets you away from everyday life": Local woodlands and community use-What makes a difference? Landsc. Res. 2005, 30, 109-146. [CrossRef]

52. Waite, S. Teaching and learning outside the classroom: Personal values, alternative pedagogies and standards. Education 2011, 39, 65-82. [CrossRef]

53. Villamagna, A.M.; Angermeier, P.L.; Bennett, E.M. Capacity, pressure, demand, and flow: A conceptual framework for analyzing ecosystem service provision and delivery. Ecol. Complex. 2013, 15, 114-121. [CrossRef] 
54. Marzano, M.; Quine, C.P.; Dandy, N. Forests for all? Considering the conservation implications of human-species interactions in the context of multifunctional forestry. In Planted Forests: Contributions to the Quest for Sustainable Societies; Springer: Dordrecht, The Netherlands, 2014; pp. 55-69.

55. Larson, C.L.; Reed, S.E.; Merenlender, A.M.; Crooks, K.R. Effects of recreation on animals revealed as widespread through a global systematic review. PLOS ONE 2016, 11, e0167259.

56. Quine, C.P.; Fuller, R.J.; Smith, K.W.; Grice, P.V. Stand management: A threat or opportunity for birds in British woodland? Ibis 2007, 149, 161-174. [CrossRef]

57. Verschuyl, J.; Riffell, S.; Miller, D.; Wigley, T.B. Biodiversity response to intensive biomass production from forest thinning in North American forests-A meta-analysis. For. Ecol. Manag. 2011, 261, 221-232. [CrossRef]

58. Mason, W.L. Changes in the management of British forests between 1945 and 2000 and possible future trends. IBIS 2007, 149, 41-52. [CrossRef]

59. Maryudi, A.; Devkota, R.R.; Schusser, C.; Yufanyi, C.; Salla, M.; Aurenhammer, H.; Rotchanaphatharawit, R.; Krott, M. Back to basics: Considerations in evaluating the outcomes of community forestry. For. Policy Econ. 2012, 14, 1-5. [CrossRef]

60. The Woodland Trust. Europe Economics 2017 The Economic Benefits of Woodland: A report for the Woodland Trust prepared by Europe Economics; The Woodland Trust: Lincolnshire, UK, 2017.

61. Quine, C.P.; Bailey, S.A.; Watts, K. Practitioner's perspective: Sustainable forest management in a time of ecosystem services frameworks: Common ground and consequences. J. Appl. Ecol. 2013, 50, 863-867. [CrossRef] [PubMed]

62. Brainard, J.; Bateman, I.J.; Lovett, A.A. The social value of carbon sequestered in Great Britain's woodlands. Ecol. Econ. 2009, 68, 1257-1267. [CrossRef]

63. Alamgir, M.; Turton, S.M.; Macgregor, C.J.; Pert, P.L. Assessing regulating and provisioning ecosystem services in a contrasting tropical forest landscape. Ecol. Indic. 2016, 64, 319-334. [CrossRef]

64. Baral, H.; Guariguata, M.R.; Keenan, R.J. A proposed framework for assessing ecosystem goods and services from planted forests. Ecosyst. Serv. 2016, 22, 260-268. [CrossRef]

65. Kueper, A.M.; Sagor, E.S.; Becker, D.R. Learning from Landowners: Examining the Role of Peer Exchange in Private Landowner Outreach through Landowner Networks. Soc. Nat. Resour. 2013, 26, 912-930. [CrossRef]

66. O'Brien, L.; Marzano, M. Volunteering in and for Scotland's Forests; Forest Research: Farnham, UK, 2011.

67. Bingley, A.; Collins, A.; Varey, S.; Oaks, R. Balancing acts of work in the third sector: Older volunteers' experience in woodland conservation. In Proceedings of the Third Sector, the State and the Market: Challenges and Opportunities in an Era of Austerity, Sheffield, UK, 28 October 2014.

68. O'Brien, L.; Morris, J. Well-being for all? The social distribution of benefits gained from woodlands and forests in Britain. Local Environ. 2014, 19, 356-383. [CrossRef]

69. O'Brien, L.; Morris, J.; Marzano, M.; Dandy, N. Promoting sustainability behaviours through forestry. Forestry: An International. J. For. Res. 2017, 90, 88-98.

70. Urquhart, J.; Courtney, P. Seeing the owner behind the trees: A typology of small-scale private woodland owners in England. For. Policy Econ. 2011, 13, 535-544. [CrossRef]

71. Van der Jagt, A.P.; Lawrence, A. Local government and urban forest governance: Insights from Scotland. Scand. J. For. Res. 2019, 34, 53-66. [CrossRef]

72. Tidey, P.; Pollard, A.; Woods, S. Characterising Community Woodlands in England and Exploring Support Needs; Forest Research: Farnham, UK, 2010. 